\title{
Contribution of Insurance Business In Nepal
}

\author{
Khom Raj Kharel ${ }^{14}$
}

\begin{abstract}
This study aims to find the contribution of insurance business in Nepalese economy. The insurance sector is assumed to be an infrastructural pillar of the financial sector of the economy. The role of insurance business has been growing importance in financial intermediation, which has received less attention than bank and stock markets. The ultimate goal of insurance business is to provide security to insurance industry according to national need by protecting all classes of the society from natural and social risks while embracing the globally accepted insurance norms. There has been significant contribution of insurance business boosting economic development of Nepal. The objective of the study is to investigate insurance business and examine its contribution on financial resources mobilizations in Nepal. For this theoretical analysis, different research studies have studied to draw the fundamental issues of insurance business in the economy. The simple statistical tools have been applied to analyze the collected data. Furthermore the findings of the study emphasize the development of insurance business and its contribution in mobilizing financial resources needs to be paid more attention in financial sector analysis and macroeconomic policy.
\end{abstract}

Keywords: Insurance industry, Financial resources, Premium earnings, Economic growth, Nepal.

\section{Introduction}

Insurance industry is assumed to be an infrastructural pillar of the financial sector and the economic growth and development as a whole. Insurance is simply known as the transfer of risk from individual to the insurance industries in lieu of a premium amount. This sector can play a significance role in financial mobility, economic growth and development. Life insurance and non-life insurance are the two wings of insurance industries. Life insurers have been selling various products of life policy, money back plans, endowment policy, accident and health related policies, children insurance plans and policies etc., whereas non-life insurers are selling various products like fire insurance, health and medical insurance, marine insurance, group accidental insurance, aviation insurance and miscellaneous insurance. Insurance industries can use their funds consisting of premiums, reserves and capital to financial claim payments and other expenses. The remaining fund is invested as per the investment directives of insurance board.

14 Dr. Kharel is an Associate Professor in Economics at Saraswati Multiple Campus, T.U. Lekhnath Marg, Kathmandu, Nepal. Email:kharelkhom@yahoo.com 
Several empirical studies suggest a strong correlation between the development of financial intermediaries and economic growth. There are two, possibly coexisting, relationships between the financial sector and economic growth. The first is the case where the financial sector has a supply-leading relationship with growth, and where economic growth can be induced through the supply of financial services. The second is a demand-following relationship where the demand for financial services can induce growth of financial institutions and their assets (Patrick,1966). Developing countries have supply-leading patterns of causality of development and considered locally incorporated insurance institutions or government owned monopolies an essential element of economic development.

These days, the economic importance of the insurance industry has been increasing in most developed countries as well as developing countries. Insurance companies form a growing part of the domestic financial sector. They have also become significant players in the international capital markets. During the 1990s, the total assets of insurance companies in developed countries grew faster than the assets of banks. Other reasons for the sector's increasing importance are the liberalization of financial systems, financial consolidation, the increasing use of contractual savings products and market-seeking approaches.

The insurance industry is closely linked with macroeconomic factors, regulation and supervision, and the achievement of national development objectives, as well as the international trade regime. Given its dual infrastructural and commercial role, this sector has attracted great interest in the context of privatization and liberalization. The $20^{\text {th }}$ conference of 'Association of Insurers and Reinsurers of Developing Countries (AIRDC)'had focused on insurance industry in developing countries with the slogan of 'Transforming the Insurance Industry in Developing Countries (Manama, 2016). It indicates that the scope of insurance industry is increasing in Nepal as well as developing countries. Similarly, the $21^{\text {th }}$ conference of AIRDC has focused on building financial resilience disaster risk financing and insurance (AIRDC,2018).

\section{Research Issues}

Insurance industries are similar to banks and capital markets as they serve the needs of business units and private households in financial intermediation. The availability of insurance service is necessary for the stability of the economy and can make the business participants accept aggravated risks. By accepting claims, insurance companies also have to pool premiums and form reserve funds. So, insurance companies are playing an important role by enhancing internal cash flow at the assured and by creating large amount of assets placed on the capital market and hence may contribute to economic growth. Insurance as a risk transfer mechanism may contribute to economic growth of a country by fostering long term investment through capital that is collected from accumulated savings from individuals. The literature on finance and growth does not, however, pay sufficient attention to the important and rising role played by non-banking financial intermediaries such as insurance companies. Similarly, there has not been deep study about the insurance business and its contribution toward financial resources mobilization yet. Hence, the research questions of the study are -

a. What is the existing status of insurance business in Nepal?

b. What is the contribution of insurance business in the economy? 


\section{Review of Literature}

Insurance industry has significance contribution in cover financial risk, liquidity mobilization and economic growth. The insurance sector links into financial sectors which has grown its importance. The theoretical studies and empirical evidence have shown that countries with better developed financial systems enjoy faster and stable long-run growth. The importance of the insurance-growth nexus is growing due to the increasing share of the insurance sector in the financial sector in almost every developing and developed country. The review of some empirical analysis on insurance-growth nexus provides information on sample coverage in time and space, methodology and variable usage and dependency.

Rule (2001) studied the growing links between the insurance and other financial sectors also emphasize the possible role of insurance companies in economic growth. Cross-shareholdings and bank-assurance as a major form of financial conglomerates and assure-finance play a rising role. Via credit default swaps (CDS) and other risk pass-through vehicles, insurance companies increasingly enter the market for credit risk, hitherto the sole domain of banks and capital markets.

Insurance sector boosts economic growth by promoting financial stability, mobilizing and channelizing savings, supporting trade, commerce, entrepreneurial activity and social programs. It is also encouraging the accumulation of new capital and fostering a more efficient allocation. Moreover, the sector reduces the amount of capital needed to cover these losses individually, thereby encouraging additional output, investment, innovation, and competition. Insurance companies have long investment horizons and can contribute to the provision of long-term finance and more effective risk management.

Arena (2006) tested whether there is a causal relationship between insurance and economic growth using Gaussian Mixture Model (GMM) and found the robust evidence that there is positive and significant causal relationship between both life and non-life insurance and economic growth. Curak et al., (2009) by implying fixed-effect model, the short and long-run relationship between economic growth and insurance sector development in Nigerian economy reveals that development of insurance sector positively and significantly affects economic growth. Verma and Bala (2013) had found the empirical evidence that life insurance has both positive as well as significant impact on the economic growth in India.

Rao (2013) remarked that economic development relies on investment which is made out of savings whereas insurance sectors mobilizes saving of people into investment for economic growth. Charumathi (2012) pointed that the insurance industries provide long term funds for the infrastructure of development and strengthen the risk taking ability of the country. A welldeveloped insurance market paves way for efficient resource allocation through the transfer of risk and mobilization of savings.

Lamm-Tennant and Dominedo (2013) pointed that the insurance sector boosts economic growth by promoting financial stability, mobilizing and channelizing savings, supporting trade, commerce, entrepreneurial activity and social programs; and encouraging the accumulation of new capital and fostering a more efficient allocation. Moreover, the sector reduces the amount of capital needed to cover these losses individually, thereby encouraging additional output, investment, innovation, and competition. Insurance companies have long investment horizons and can contribute to the provision of long-term finance and more effective risk management. 
Sibindi and Godi (2014) had investigated the causal relationship between the insurance sector and economic growth in South Africa. The study found the evidence that the economic growth spurs the development of the long-term insurance sector as well as the total insurance.

Cristea et al., (2014) had established that there was a high correlation based on the causal link between the insurance market, measured by the degree of insurance penetration and the degree of density and economic growth, measured by GDP per capita. The correlation found between the GDP per capita and insurance share in GDP shows a greater influence of the life insurance market rather than the non-life insurance.

Hussein (2019) has examined the role of insurance sector in Oman economy using real gross domestic product as representative for Oman economy performance. The results showed that there was a positive relationship between insurance sector and economic growth in Oman for the study period. He suggested that there should be given more attention to the financial sector development with more concentration on insurance sector development to ensure economic growth.

By reviewing various research papers can be reached into conclusion that the availability of insurance services is essential for the stability of the economy and can make the business participants accept aggravated risks. By accepting claims, insurance companies also have to pool premiums and form reserve funds. So, insurance companies are playing an important role by enhancing internal cash flow at the assured and by creating large amount of assets placed on the capital market and hence may contribute to economic growth. Compared to the vast literature focusing on bank, stock and bond markets and their respective environment, the insurance sector has hardly been investigated in its role vis-à-vis economic growth.

\section{Research Gap}

There is still lack of positive attitude about insurance while it has also not been on government's priority and cheap life insurance is yet to come within the reach of commoners. Besides, the lack of transparency and life insurance price also hampered monitoring in the sector in the past, for life insurance savings. The literature on finance and growth does not, however, pay sufficient attention to the important and rising role played by non-banking financial intermediaries such as insurance companies. Similarly, there has not been deep study about the insurance industry and its contribution on economic growth yet.

\section{Objectives}

The general objective of this paper is to examine the contribution of insurance industries in economic growth of Nepal using determinants of insurance like total insurance premium, life insurance premium, non-life insurance premium and investment using data from 2001/01 to $2019 / 20$ based on theoretical and empirical evidence. Hence, the main objective of this paper is to examine the development of insurance industries and its contribution in accelerating economic growth of Nepal.

\section{Methodology}

The study is the descriptive and analytical in nature. So the descriptive research design has been applied. In descriptive and analytical research design, descriptive research design, different tables, diagram and examples has been presented as necessary. The study is primarily based on 
secondary data and information that were collected from various annual reports, journals, articles and publications made by Government of Nepal, Ministry of Finance, Insurance Board, insurance companies of Nepal, and web sites. The study period covered is 17 years from the fiscal year 2001/02 to 2018/19.The econometric and statistical tools and models has been applied to examine the impact of insurance premium on GDP. The impact of total insurance premium (TIP) on GDP is estimated by:

$$
G D P_{t}=\alpha_{0}+\beta T I P_{t}+\varepsilon_{t} \ldots \ldots \ldots \ldots \ldots \ldots \ldots(i)
$$

Where, GDP is the Gross Domestic Product. The $\alpha_{0}$ is constant; $\beta$ is coefficient parameter. The GDP is expected to be increase due to increase in total insurance premium (TIP).

\section{Results and Discussion}

\section{Existing Status of Insurance Industries in Nepal}

For the development of insurance industry in Nepal, Insurance Committee was established on $14^{\text {th }}$ May, 1969 has been carrying out operations as a regulatory agency by systemizing, regulating, developing, and controlling the insurance industry. There are altogether 40 insurance companies under which 19 are life insurance companies, 20 non-life insurance companies and one reinsurance company in Nepal upto 2019.companies have been carrying out life insurance industry, 20 companies in non-life insurance, while one insurance company is engaged in reinsurance totaling 40 insurance companies. On the basis of ownership, 3 are government, 3 companies are operating as a branch of foreign insurance company, 3 are joint venture with foreign companies and 31 are private companies. As per the seven provinces, the insurance companies have also expanded their branches in the seven provinces as shown in the table-1:

Table 1: Branches of Life and Non-life Insurance up to 2019

\begin{tabular}{|l|c|c|c|}
\hline \multicolumn{1}{|c|}{ Provinces } & Life Insurance & Non-life Insurance & Total \\
\hline Province-1 & 228 & 115 & 343 \\
\hline Province-2 & 172 & 91 & 263 \\
\hline Province-3 & 327 & 226 & 553 \\
\hline Gandaki & 129 & 95 & 224 \\
\hline Province-5 & 192 & 117 & 309 \\
\hline Karnali & 98 & 28 & 126 \\
\hline Sudur Pashchim & 144 & 47 & 191 \\
\hline \multicolumn{1}{|c|}{ Total } & $\mathbf{1 2 9 0}$ & $\mathbf{7 1 9}$ & $\mathbf{2 0 0 9}$ \\
\hline
\end{tabular}

Source: Beema Samiti, 2019.

Table-1 depicts the province-wise branches of life insurance and non-life insurances of Nepal. There are altogether 2,009 branches whereas 1,290 branches of life insurance and 719 branches of non-life insurances up to 2018/19. According to provinces, Province-3 has the highest number of insurance branches and Karnali province represents the lowest number of branches of insurance companies. The table-1 is shown in the figure-1: 
Figure 1: Province wise Branches of Life and Non-life Insurance up to 2018/19.

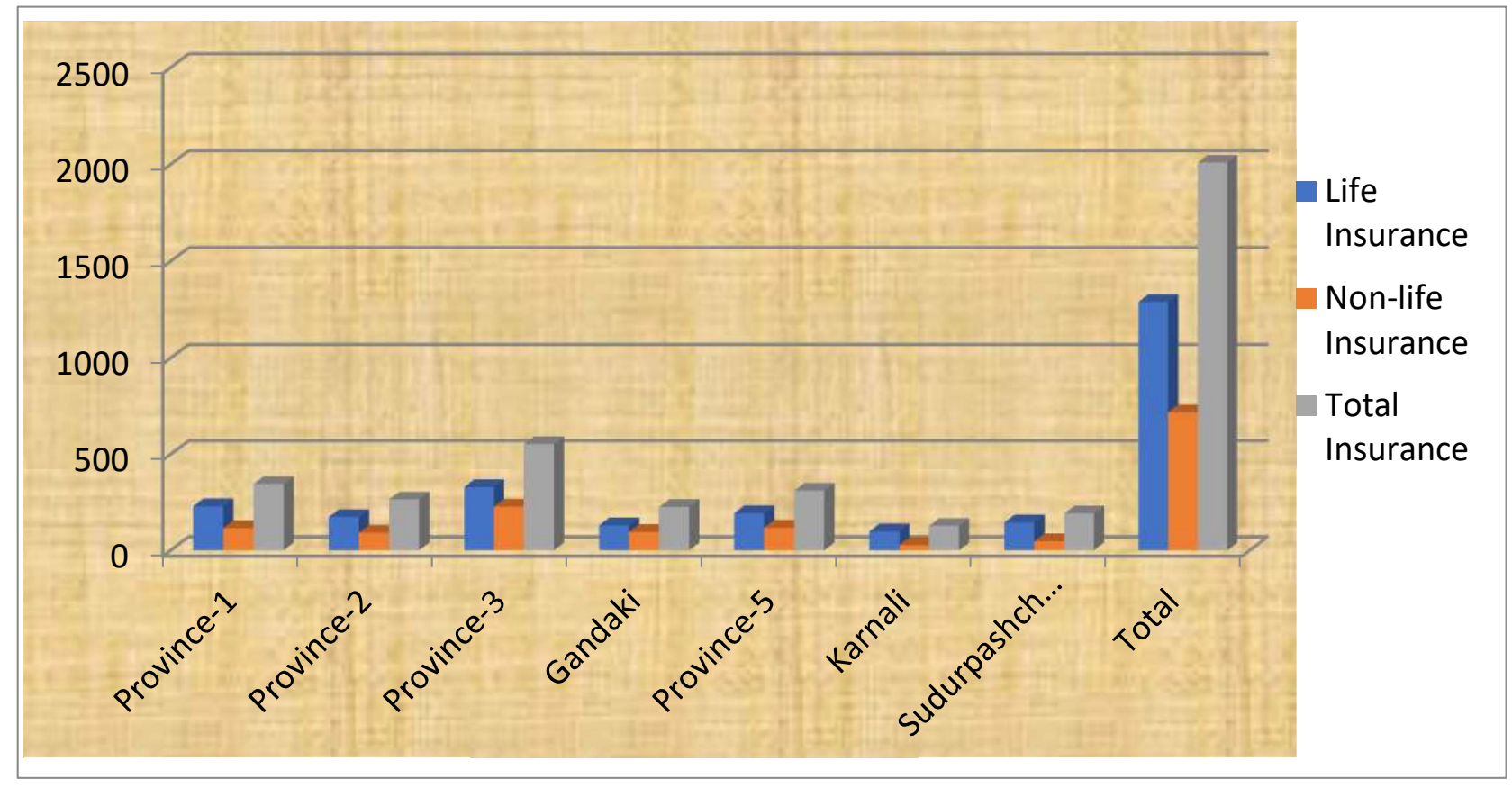

Source: Table-1.

The figure-1 depicts the province-wise expansion of branches of life insurance and non-life insurances in Nepal up to 2018/19.Province-3 shows the highest number of branches whereas the Karnali Province shows the lowest one.

\section{Total Insurance Premium Earnings and Growth Rate}

The total earnings as premium of life and non-life insurance companies has been increasing at different fiscal years at different rate. Earnings of insurance companies from their insurance premium have been increasing in recent years. It was Rs. 3.513 billion in FY 2001/02. With the gradual increase in subsequent fiscal years, it has been estimated to be Rs.95.370 billion in FY 2018/19.

Table 2: Total Insurance Premium and Growth Rate from 2001/02 to 2018/19.

\begin{tabular}{|c|c|c|c|c|c|}
\hline $\begin{array}{c}\text { Fiscal } \\
\text { Years }\end{array}$ & $\begin{array}{c}\text { Total Insurance } \\
\text { Premium (Rs. in billion) }\end{array}$ & $\begin{array}{c}\text { Growth } \\
\text { Rate } \\
\mathbf{( \% )}\end{array}$ & $\begin{array}{c}\text { Fiscal } \\
\text { Years }\end{array}$ & $\begin{array}{c}\text { Total Insurance } \\
\text { Premium (Rs. in billion) }\end{array}$ & $\begin{array}{c}\text { Growth } \\
\text { Rate } \\
\mathbf{( \% )}\end{array}$ \\
\hline $2001 / 02$ & 3.513 & $62.94 \%$ & $2010 / 11$ & 17.666 & $15.68 \%$ \\
\hline $2002 / 03$ & 4.041 & $15.03 \%$ & $2011 / 12$ & 22.014 & $24.61 \%$ \\
\hline $2003 / 04$ & 4.747 & $17.47 \%$ & $2012 / 13$ & 24.280 & $10.29 \%$ \\
\hline $2004 / 05$ & 5.850 & $17.61 \%$ & $2013 / 14$ & 30.431 & $25.33 \%$ \\
\hline $2005 / 06$ & 6.844 & $16.92 \%$ & $2014 / 15$ & 37.330 & $22.67 \%$ \\
\hline $2006 / 07$ & 7.912 & $19.09 \%$ & $2015 / 16$ & 46.970 & $25.82 \%$ \\
\hline $2007 / 08$ & 9.342 & $18.07 \%$ & $2016 / 17$ & 55.000 & $17.10 \%$ \\
\hline $2008 / 09$ & 11.056 & $18.35 \%$ & $2017 / 18$ & 77.880. & $41.6 \%$ \\
\hline $2009 / 10$ & 15.263 & $38.05 \%$ & $2018 / 19$ & 95.370 & $22.46 \%$ \\
\hline
\end{tabular}

Source: MoF., Economic Surveys (2010/11 \& 2018/19) \& Beema Samiti,2019. 
Table-2 depicts the total earnings through insurance premium and growth rate from 2001/02 to $2018 / 19$. Total insurance premium has been increasing at different rates in different years. The highest growth rate was 62.94 percent in 2001/02 and the lowest growth rate was 10.29 percent in 2012/13. The growth rate of premium is shown in the figure-2.

Figure-2: Growth Rate of Premium of Insurance Industries (2001/02-2018/19)

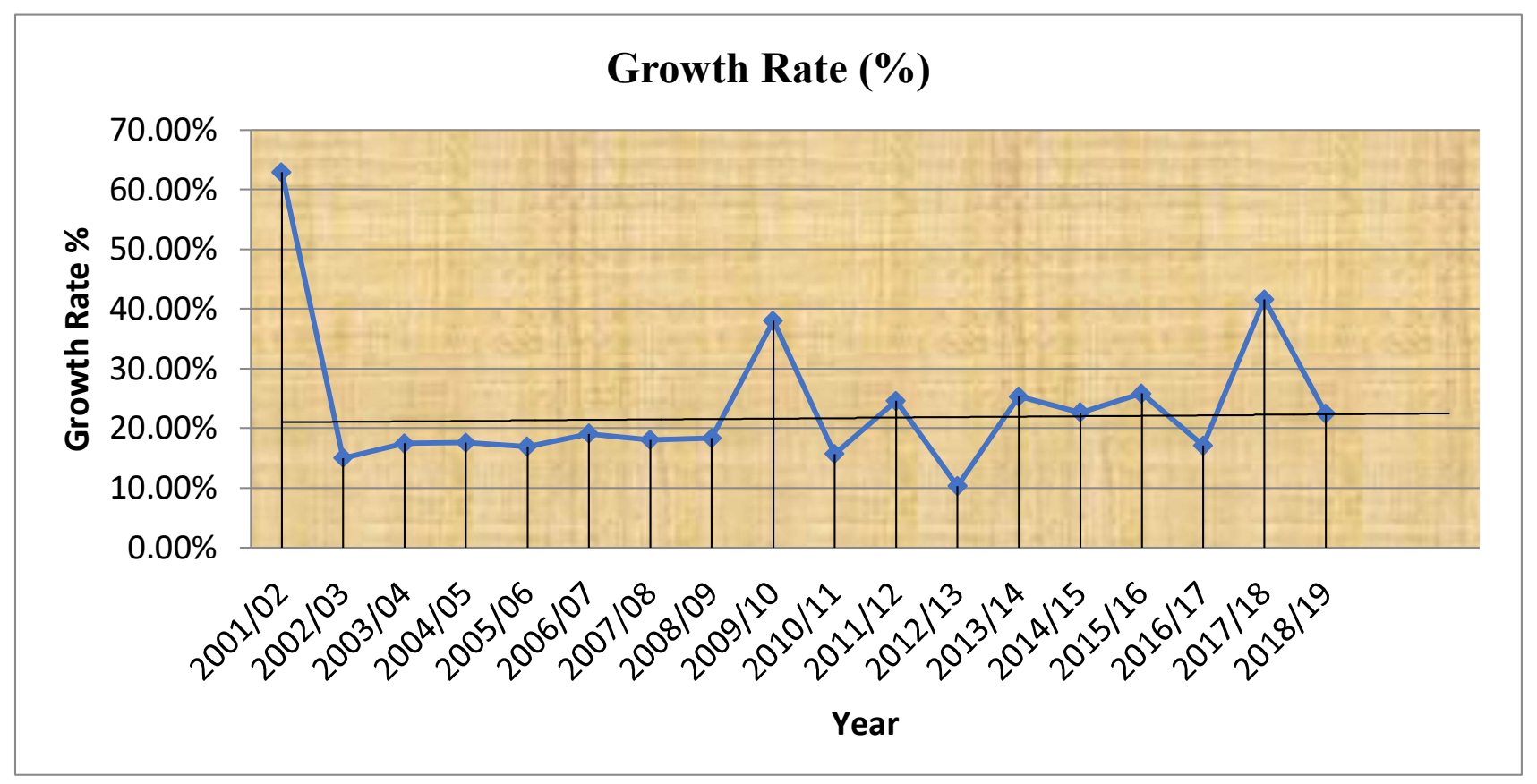

Source: Table 2.

\section{Contribution of Insurance Premiums to GDP Ratio}

The ratio of insurance premiums to GDP had stood at 0.82 percent in FY 2001/02. Such ratio which had been hovering around 1.44 percent since 2011/12, it was projected to remain at 2.76 percent in FY 2018/19. Such contributions were recorded at different rates at different fiscal years as shown in the Table-3.

Table-3: Contribution of Insurance Premium to GDP (Rs. in billion)

\begin{tabular}{|l|c|c|c|c|c|c|c|}
\hline $\begin{array}{l}\text { Fiscal } \\
\text { Years }\end{array}$ & $\begin{array}{c}\text { Total } \\
\text { Insurance } \\
\text { Premium }\end{array}$ & GDP & $\begin{array}{c}\text { \%o of } \\
\text { Insurance } \\
\text { Premium of } \\
\text { GDP }\end{array}$ & $\begin{array}{c}\text { Fiscal } \\
\text { Years }\end{array}$ & $\begin{array}{c}\text { Total } \\
\text { Insurance } \\
\text { Premium }\end{array}$ & GDP & $\begin{array}{c}\text { \% of } \\
\text { Insurance } \\
\text { Premium } \\
\text { of GDP }\end{array}$ \\
\hline $2001 / 02$ & 3.513 & 430.396 & 0.82 & $2010 / 11$ & 17.666 & 1366.954 & 1.29 \\
\hline $2002 / 03$ & 4.041 & 460.325 & 0.88 & $2011 / 12$ & 22.014 & 1527.344 & 1.30 \\
\hline $2003 / 04$ & 4.747 & 500.699 & 0.95 & $2012 / 13$ & 24.280 & 1695.011 & 1.43 \\
\hline $2004 / 05$ & 5.850 & 548.485 & 1.07 & $2013 / 14$ & 30.431 & 1964.54 & 1.55 \\
\hline $2005 / 06$ & 6.644 & 611.118 & 1.09 & $2014 / 15$ & 37.330 & 2130.150 & 1.75 \\
\hline $2006 / 07$ & 7.912 & 675.859 & 1.17 & $2015 / 16$ & 46.970 & 2253.163 & 2.08 \\
\hline $2007 / 08$ & 9.342 & 755.257 & 1.24 & $2016 / 17$ & 55.000 & 2674.49 & 2.06 \\
\hline $2008 / 09$ & 11.056 & 909.309 & 1.22 & $2017 / 18$ & 77.880. & 3044.93 & 2.56 \\
\hline $2009 / 10$ & 15.263 & 1060.881 & 1.44 & $2018 / 19$ & 95.370 & 3458.79 & 2.76 \\
\hline
\end{tabular}

Source: MoF (2010/11 \&2018/19) and Beema Samiti, 2019. 
Table-3 depicts the insurance premium to GDP ratio from 2001/02 to 2018/19. During the study period, the insurance premium to GDP ratio is between 0.82 to 2.76 percent. Before $2015 / 16$, the contribution of insurance premium to GDP ratio was below 2 percent whereas after 2015/16, the insurance premium to GDP ratio has found more than 2 percent. The insurance premium to GDP ratio is presented in figure-3.

Figure-3: Growth Rate of Insurance industry Contribution to GDP

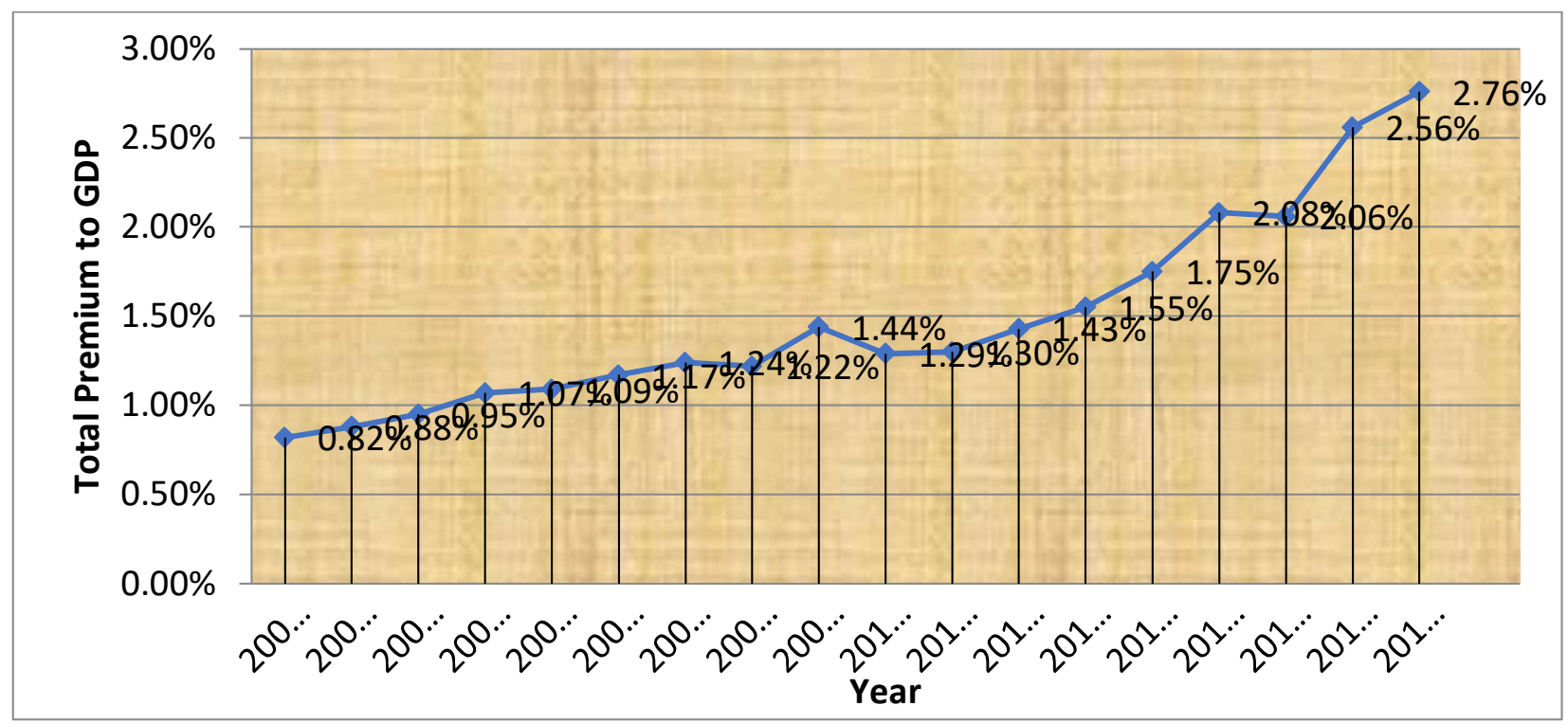

Source: Table-3.

\section{Investment of Insurance Industry in Nepal}

The insurers have been investing their investable amount in a long-term manner. Government securities bond, debentures, fixed deposits on banks and financial institutions, shares, loans secured by insurance policies etc. The investable fund of life and non-life insurance companies has been increasing continuously. The investible amount with life and non-life insurers between fiscal years 2001/02 and 2018/19 stood at Rs.10.054 billion in the fiscal year 2001/02 whereas it was Rs.261.55 billion in the fiscal year 2018/19. The details of investment made in life and Non-life insurance industry has been in the table and figure below:

Table-4: Investment on Life and Non-Life Insurance industry (2001/02-2018/19)

\begin{tabular}{|c|c|c|c|c|c|c|c|}
\hline \multirow[b]{2}{*}{$\begin{array}{l}\text { Fiscal } \\
\text { Years }\end{array}$} & \multicolumn{3}{|c|}{ Investment (Rs. in Billion) } & \multirow[b]{2}{*}{$\begin{array}{l}\text { Fiscal } \\
\text { Years }\end{array}$} & \multicolumn{3}{|c|}{ Investment (Rs. in Billion) } \\
\hline & $\begin{array}{c}\text { Life } \\
\text { Insurance }\end{array}$ & $\begin{array}{c}\begin{array}{c}\text { Non-life } \\
\text { Insurance }\end{array} \\
\end{array}$ & Total & & $\begin{array}{c}\text { Life } \\
\text { Insurance }\end{array}$ & $\begin{array}{c}\text { Non-life } \\
\text { Insurance }\end{array}$ & Total \\
\hline $2001 / 02$ & 7.189 & 2.865 & 10.054 & $2010 / 11$ & 36.467 & 7.473 & 43.94 \\
\hline $2002 / 03$ & 7.963 & 2.456 & 10.419 & $2011 / 12$ & 54.500 & 8.645 & 63.145 \\
\hline $2003 / 04$ & 9.779 & 2.676 & 12.455 & $2012 / 13$ & 64.343 & 10.217 & 74.56 \\
\hline $2004 / 05$ & 11.8002 & 3.031 & 14.8312 & $2013 / 14$ & 79.13 & 12.231 & 91.36 \\
\hline $2005 / 06$ & 15.2011 & 3.211 & 18.4121 & $2014 / 15$ & 97.125 & 14.974 & 112.099 \\
\hline $2006 / 07$ & 18.3976 & 3.4475 & 21.8451 & $2015 / 16$ & 118.128 & 21.832 & 139.96 \\
\hline $2007 / 08$ & 20.533 & 4.1831 & 24.533 & $2016 / 17$ & 148.623 & 23.214 & 171.84 \\
\hline NA & NA & NA & NA & $2017 / 18$ & 196.743 & 32.797 & 229.54 \\
\hline $2009 / 10$ & 26.5162 & 5.0079 & 31.5241 & $2018 / 19$ & 225.178 & 36.678 & 261.86 \\
\hline
\end{tabular}

Source: MoF, Economic Survey (2005/06\&2018/19). 
Table-4 represents the investment on life insurance, non-life insurance and total insurance from 2001/02 to 2018/19. The investment on insurance sectors has been increasing during the study periods. The table- 4 is presented in the figure- 4 :

Figure-4: Investment on Made Life and Non-Life Insurance Industry

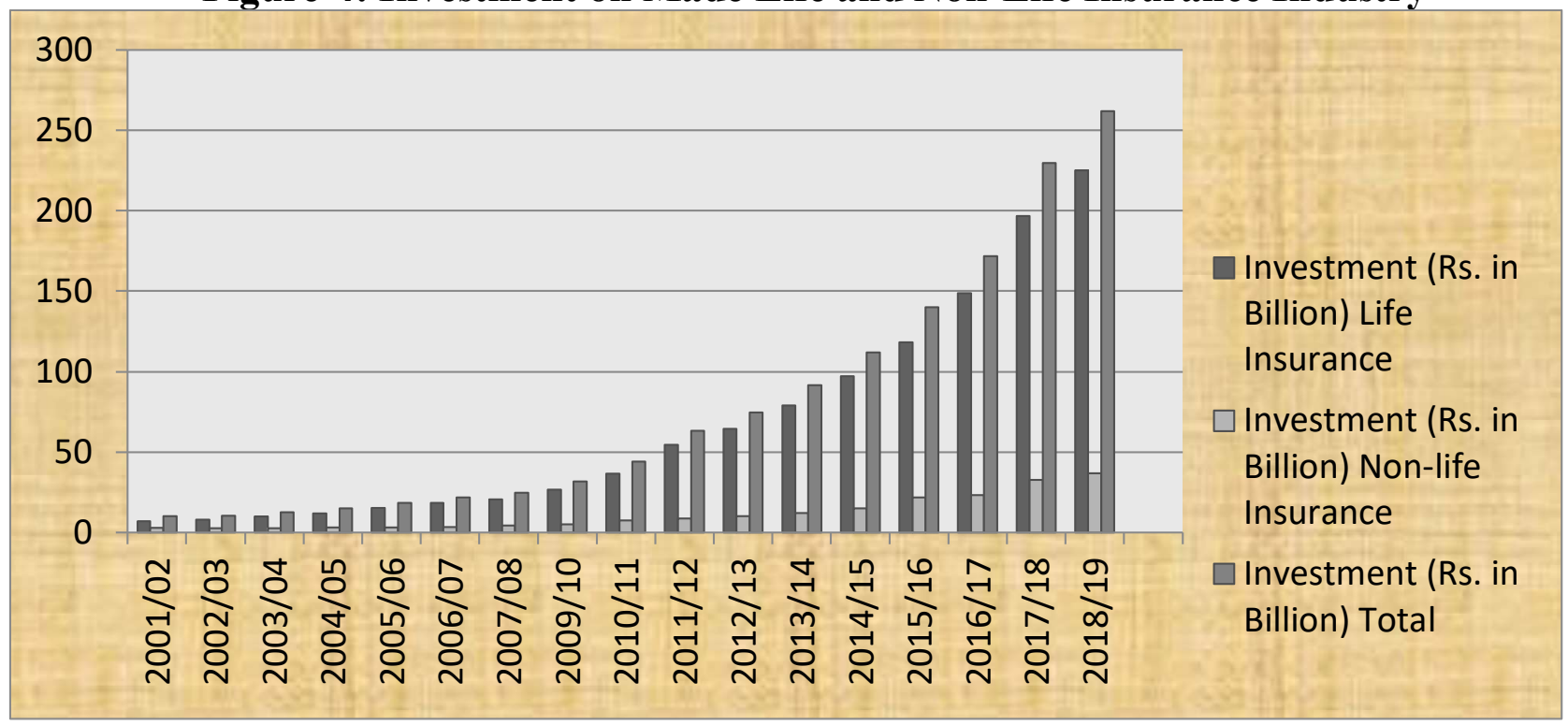

Source: Table-4.

\section{Financial Resources and Utilization of Insurance Industry}

The gross financial resources and utilization of life insurance and non-life insurance companies in the country have been increasing at different rates in the study period which is shown in the table from $2008 / 09$ to $2018 / 19$ as below:

Table-5: Financial Resources and Utilization of Insurance Business(Rs. in Billion)

\begin{tabular}{|l|c|c|c|}
\hline Fiscal Years & Life Insurance & Non-life Insurance & Total Financial Resources \\
\hline $2008 / 09$ & 29.638 & 7.377 & 37.015 \\
\hline $2009 / 10$ & 38.120 & 9.340 & 47.460 \\
\hline $2010 / 11$ & 48.52 & 13.32 & 61.82 \\
\hline $2011 / 12$ & 58.59 & 15.23 & 73.82 \\
\hline $2012 / 13$ & 64.82 & 16.33 & 81.15 \\
\hline $2013 / 14$ & 71.04 & 17.08 & 88.12 \\
\hline $2014 / 15$ & 103.70 & 25.75 & 129.75 \\
\hline $2015 / 16$ & 129.88 & 30.06 & 159.94 \\
\hline $2016 / 17$ & 129.81 & 33.22 & 163.77 \\
\hline $2017 / 18$ & 199.56 & 41.07 & 240.63 \\
\hline $2018 / 19$ & 230.67 & 83.22 & 313.89 \\
\hline
\end{tabular}

Source: MoF, Economic Survey (2008/09-2018/19).

Table-5 depicts the financial resources and utilization of life and non-life insurance from $2008 / 09$ to $2018 / 19$. The total financial resources of insurance business and its utilization has been Rs.313.89 billion up to 2018/19. Out of this amount, life insurance and non-life insurance companies have share equivalent to Rs.230.67 billion and Rs.83.22 billion respectively. This figure is 30.44 percent higher than that of the corresponding period of FY 2018/19. Data shows the increasing trends of financial resource in the study period. The table presented in the figure 6 


\section{Figure-6: Financial Resources and Utilization of Life and Non-life Insurances}

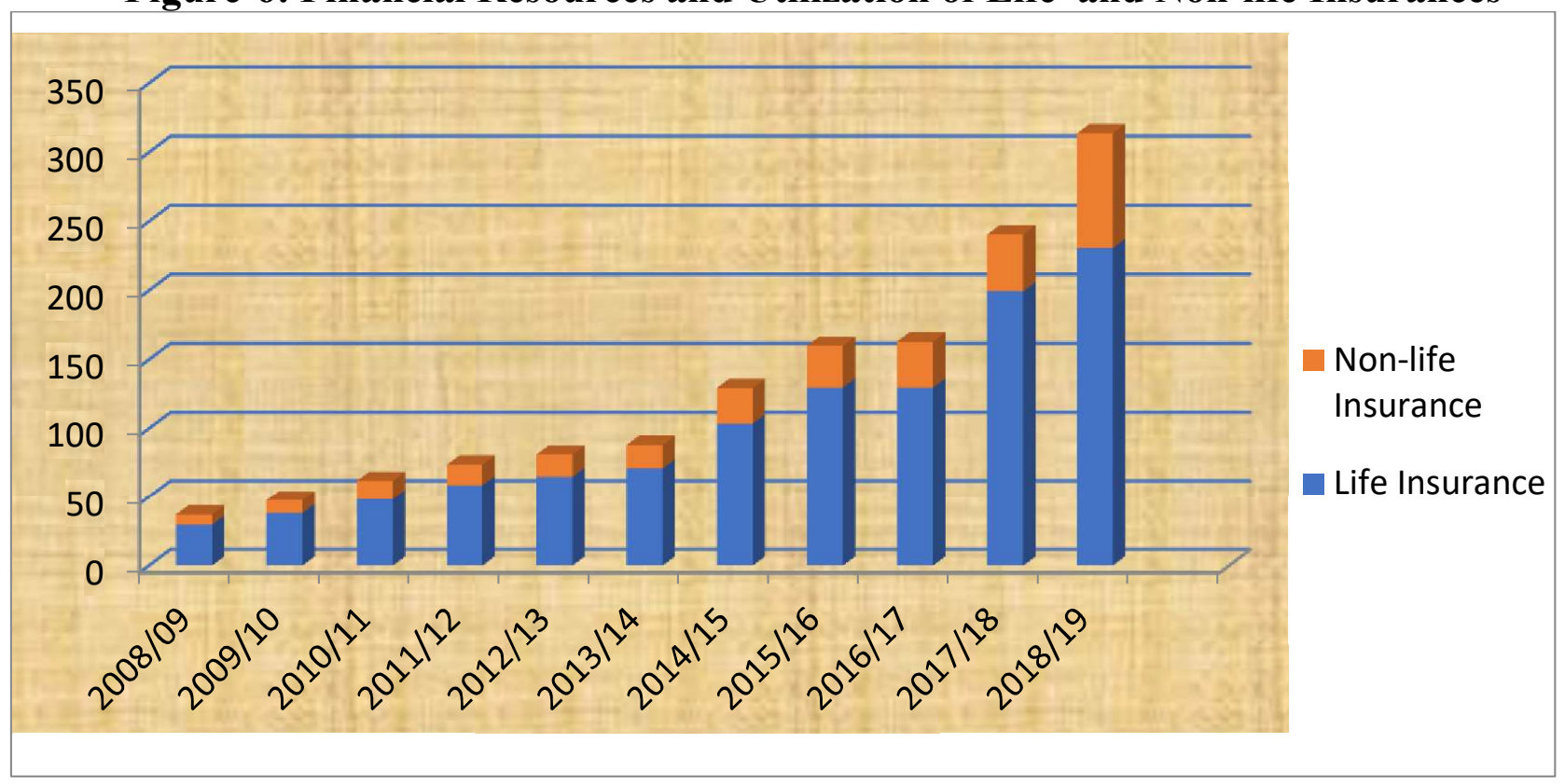

Source: Table-5.

\section{Impact of Total Insurance Premium to GDP}

There is strong positive relationship between total insurance premium and GDP@, prevailing price during $2001 / 02-2018 / 19$. The results are statistically significant $\left(\mathrm{p}<0.05, \mathrm{R}^{2}=\right.$ 0.942 ), indicates that total insurance premium account for 94.2 percent of the variance in GDP. These results show that total insurance premium significantly influences GDP (Table-6).

Table-6: Regression Analysis Total Insurance Premium and GDP

\begin{tabular}{|c|c|c|c|c|c|c|c|c|c|c|c|c|}
\hline \multicolumn{13}{|c|}{ Model: GDP $=\alpha+\beta$ TIP $+\mathrm{e}$} \\
\hline \multicolumn{13}{|c|}{ Model Summary } \\
\hline \multirow[b]{2}{*}{ Model } & \multirow[b]{2}{*}{$\mathrm{R}$} & \multirow[b]{2}{*}{$\mathrm{R}^{2}$} & \multirow{2}{*}{\multicolumn{2}{|c|}{$\begin{array}{l}\text { Adjusted } \\
\mathrm{R}^{2}\end{array}$}} & \multirow{2}{*}{\multicolumn{2}{|c|}{$\begin{array}{l}\text { Std. Error } \\
\text { of the } \\
\text { Estimate }\end{array}$}} & \multicolumn{6}{|c|}{ Change Statistics } \\
\hline & & & & & & & \multicolumn{3}{|c|}{\begin{tabular}{c|c} 
R-Square & $F$ \\
Change & Change
\end{tabular}} & df1 & df2 & $\begin{array}{l}\text { Sig. F } \\
\text { Change }\end{array}$ \\
\hline 1 & \multirow[t]{2}{*}{$0.970^{\mathrm{a}}$} & \multirow[t]{2}{*}{.942} & \multicolumn{2}{|c|}{0.938} & \multicolumn{2}{|c|}{237.50984} & \multicolumn{2}{|c|}{0.942} & 58.523 & \multirow[t]{2}{*}{1} & \multirow[t]{2}{*}{17} & 0.000 \\
\hline \multicolumn{9}{|c|}{ Coefficients } & & & & \\
\hline \multirow{2}{*}{\multicolumn{4}{|c|}{ Model }} & \multicolumn{4}{|c|}{$\begin{array}{l}\text { Unstandardized } \\
\text { Coefficients }\end{array}$} & \multicolumn{3}{|c|}{$\begin{array}{c}\text { Standardized } \\
\text { Coefficients }\end{array}$} & \multirow{2}{*}{$\mathrm{T}$} & \multirow{2}{*}{ Sig. } \\
\hline & & & & & 3 & Std. I & rror & & Beta & & & \\
\hline \multirow[b]{2}{*}{1} & \multicolumn{3}{|c|}{ Constant $(\alpha)$} & \multicolumn{2}{|c|}{534.539} & \multicolumn{2}{|c|}{79.768} & & & & 6.701 & 0.000 \\
\hline & \multicolumn{3}{|c|}{$\begin{array}{l}\text { Total Insurance Premium } \\
(\mathrm{TIP})(\beta) \text { (Rs. in Billion) }\end{array}$} & \multicolumn{2}{|c|}{34.601} & \multicolumn{2}{|c|}{2.152} & & 0.970 & & 16.079 & 0.000 \\
\hline
\end{tabular}

Source: Calculated by Author Based on Table-.3. 


\section{Conclusion}

The objective of conducting research paper is to study the insurance industries for accelerating economic growth in Nepal. It has pointed to the role of insurance in economic development. There has been significant contribution of insurance business in economic growth, efficiently allocates resources, manage risk, and mobilize long-term savings and the insurance sector, for achieving the determined objectives, the insurance companies should operate on a financially sound basis. A well-developed insurance sector can ensure overall efficiency of the financial system by reducing transaction costs, creating liquidity, and facilitating economies of scale in investment. A sound regulatory and supervisory system is necessary for maintaining efficient, safe, fair and stable insurance markets and for promoting growth and competition in the sector. Sound macroeconomic policies are also essential for the effective performance of insurance supervisory regimes.

The insurance sector has been undergoing a major transformation in recent years because of globalization, revolution in information technology, and changes in demographic trends. In the context of Nepal, the approach of insurance industry of the people is quite small. Around 22 percent people have insurance excess in Nepal. Today, most policymakers have concluded that liberalizing financial intermediation would strengthen financial markets and would be more conducive to sustainable economic growth. There is high scope of insurance industry in Nepal. Though, the insurance business has not been success due to resource shortage, narrow investment sectors and public capacity etc.

\section{References}

AIRDC (Association of Insurers and Reinsurers of Developing Countries) (2016).Transformation of Insurance Industries in Developing Countries, $20^{\text {th }}$ Conference of AIRDC in Bahrain, 26-29 $9^{\text {th }}$.

AIRDC (Association of Insurers and Reinsurers of Developing Countries) (2018).Building Financial Resilience Disaster Risk Financing and Insurance, $21^{\text {th }}$ Conference of AIRD) in Nepal, Kathmandu, Nepal. 25-26 ${ }^{\text {th }}$.

Arena, M. (2006). Does insurance market activity promote economic growth? A cross-country study for industrialized and developing countries. Policy Research Working Paper, No.4098, World Bank, Washinton, DC, USA.

Beema Samiti(2019). Insurance News and Ideas 2019. Beema Samiti Nepal, Lalitpur, Nepal.

Charumathi, B. (2012). On the determinants of profitability of Indian life insurers- An empirical study. Proceedings of the World Congress on Engineering.Vol I WCE 2012, July 4-6, London, U.K.

Cristea, M., Marcu, N. \& Carstina, S. (2014). The relationship between insurance and economic growth in Romania compared to the main results in Europe: A theoretical and empirical analysis. Procedia economics and finance 8 (2014), 226-235.

Ćurak et al., (2009). Insurance sector development and economic growth in transition countries. International Research Journal of Finance and Economics, Vol 11,Issue 4. 
Hussein, M. A. \& Alam, M. S. (2019). The role of insurance sector in the development of the rconomy of Oman. Global Journal of Economics and Business, Vol.6,No.2, 356-364.

M. Subba Rao, R. S. (2013). Contribution of insurance sector to growth and development of the Indian economy. IOSR. Journal of Business and Management (IOSR-JBM), 7 (4), 45-52.

MoF (Ministry of Finance) (2010). Economic Survey-2010/11.Kathmandu: Government of Nepal.

MoF (Ministry of Finance) (2018). Economic Survey-2018/19. Kathmandu: Government of Nepal.

Rule, D. (2001). Risk transfer between banks, insurance companies and capital markets. financial stability, Review No. 11:127-159, http://www.bankofengland.co.uk.

Sibindi, A. B. \& Godi, N. J. (2014). Insurance sector development and economic growth: Evidence from South Africa. Corporate Ownership of Control, Vol.11,Issue 4,pp.530-538.

United Nations (2007). Trade and Development Aspects of Insurance Services and Regulatory Frameworks. New York \& Geneva.

Verma, A. \& Bala, R. (2013). The relationship between life insurance and economic growth: Evidence from India. Global Journal of Management and Business Studies, 3 (4), 413-422.

Ward, D. \& Zurbruegg, R. (2000). Does insurance promote economic growth? Evidence from OECD Countries. The Journal of Risk and Insurance, 67(4): 489-506. 